\title{
AVOIDANCE OF SIDE-REACTIONS AND LOSS OF DRUG EFFICACY DURING LONG-TERM ADMINISTRATION OF CARBONIC ANHYDRASE INHIBITORS BY CONCOMITANT SUPPLEMENTAL ELECTROLYTE ADMINISTRATION*
}

BY

\author{
J. DRAEGER, R. GRÜTTNER, AND W. THEILMANN
}

From the Department of Ophthalmology (Director: Prof. H. Sautter, M.D.) and the Department of Pediatrics (Director: Prof. K. H. Schäfer, M.D.), Hamburg University School of Medicine

Although all authors agree on the clinical usefulness of glaucoma therapy with carbonic anhydrase inhibitors, some advise against continued long-term administration of the compounds (Becker, 1954; Breinin and Görtz, 1954) for two reasons:

(1) The occasional incidence of general side-reactions such as paraesthesiae, nausea, lassitude, and even transitory myopia during long-term administration or with large doses of carbonic anhydrase inhibitors.

(2) The gradual appearance of resistance to the drugs which occurs in some patients so that the initial control tension is not maintained.

Some investigators have questioned whether this gradual loss of efficacy during long-term administration is related to a simultaneous alteration in the electrolyte balance. If this were true (because of excessive electrolyte loss), it should be possible to correct it by supplementary administration of the salts in question. This would tend to correct the electrolyte balance and re-establish the conditions required for the optimal action of the carbonic anhydrase inhibitor.

The present study was designed to elucidate these questions, and to confirm or deny the premises on which they were based.

High concentrations of the enzyme carbonic anhydrase are found in the tubule cells of the kidney and in the eye, mainly in the ciliary body. It catalyses the process:

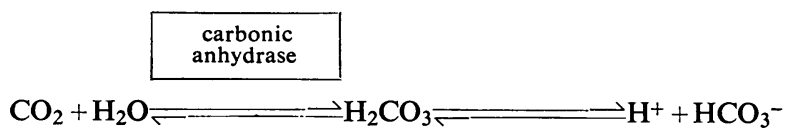

Carbonic anhydrase also promotes, in the ciliary body, the formation of bicarbonate ions. Their presence in the aqueous humour leads to higher electrolyte concentrations which in turn cause an increase in the osmotic pressure of the aqueous. This gradient of osmotic pressure between the aqueous and the protoplasm of the ciliary body determines how much aqueous is formed.

* Received for publication December 12, 1962. 
By drug-induced inhibition of carbonic anhydrase activity, it is possible to reduce the bicarbonate content of the aqueous and thereby the gradient of osmotic pressure and the amount of aqueous formed. Even when therapy fails to correct an inadequate aqueous outflow, it can lower the intra-ocular pressure by reducing the rate of aqueous formation. However, this mechanism of action of the carbonic anhydrase inhibitors also engenders undesirable alterations in the electrolyte balance of the whole organism. If the drug is administered over prolonged periods of time, the body is not capable of reestablishing a normal acid-base balance, and is in the state of marginal anabolic compensation; metabolic acidosis persists and the diuretic effect of the carbonic anhydrase inhibitor declines. This correlation between the efficacy of acetazolamide and the electrolyte balance was pointed out by Hoffmeister and Kruck $(1956,1957)$ and by Raisp (1959). These authors found that electrolyte imbalance can be compensated for by the administration of supplementary potassium, thereby maintaining the diuretic effect of acetazolamide.

In general, physicians recommend supplementary potassium during the long-term administration of carbonic anhydrase inhibitors because it has been shown that it not only re-establishes the diuretic effect but also helps to prevent untoward side-reactions.

It was natural, therefore, to consider supplementary potassium in the study of carbonic anhydrase inhibitors in ophthalmology, to discover how far it is beneficial to the individual in counteracting resistance to therapy. We considered it important to continue our observations as long as possible, since both the side-reactions and the decrease in efficacy appear very gradually.

\section{Material and Methods}

In order to include in our studies the changes in metabolism and in aqueous dynamics, the serum concentrations of sodium, potassium, and chloride, and the alkali reserve, as well as the urinary sodium, potassium, and chlorides, the $\mathrm{pH}$ and daily volume were determined several times during a 5-month observation period of 23 patients ( 43 eyes). The type of glaucoma and previous treatment are summarized in Table I. The intra-ocular pressure, rate of aqueous flow, and adequacy of outflow were measured at the same time.

TABLE I

SUMMARY OF 25 PATIENTS (43 EYES) RECEIVING ACETAZOLAMIDE AND POTASSIUM SUPPLEMENTS

\begin{tabular}{l|l|c|c|c|c}
\hline \multirow{2}{*}{ Glaucoma } & \multicolumn{3}{|c|}{ Previous Therapy } & Total \\
\cline { 3 - 6 } \multicolumn{2}{l|}{} & None & Conservative & $\begin{array}{c}\text { Surgical and } \\
\text { Conservative }\end{array}$ & \\
\hline Simple & $\begin{array}{l}\text { Patients } \\
\text { Eyes }\end{array}$ & 12 & 8 & 6 & 22 \\
\hline \multirow{2}{*}{ Secondary } & $\begin{array}{r}\text { Patients } \\
\text { Eyes }\end{array}$ & 1 & - & 11 & 37 \\
\hline
\end{tabular}


For the first 6 weeks of the observation period acetazolamide* only was given in divided doses of $125 \mathrm{mg}$. three times a day. Subsequently, daily doses of $1 \mathrm{~g}$. potassium chloride were added for 8 weeks and then increased to $2 \mathrm{~g}$. daily for another 8 weeks. For comparative purposes, some patients received potassium bicarbonate in amounts equal to the dosage of the chloride form.

In some patients with chronic congestive glaucoma experiencing an acute rise in intra-ocular pressure sufficient acetazolamide to produce a fall in pressure (250 to $500 \mathrm{mg}$.) was administered intravenously, and this was followed immediately by the infusion of a corresponding amount of potassium chloride. $\dagger$ By this procedure it was possible to counteract any alteration in the electrolyte balance which might occur more rapidly after such large doses of acetazolamide. It also eliminated such side-reactions as the excessive vomiting which occurs in some individuals after oral medication. Patients were studied weekly or biweekly, and care was taken that the time, food intake, and medication were the same.

Each time a patient was examined the intra-ocular pressure was recorded with the Goldmann tonometer, and then binocular tonographic tracings (Draeger, 1959a) were done (Fig. 1), and the findings computed by the formula of Grant $(1950,1951)$. For this purpose tables were drawn up which considered the exact coefficient of rigidity in each individual and allowed direct reading of the adequacy of outflow (Draeger, 1959b).

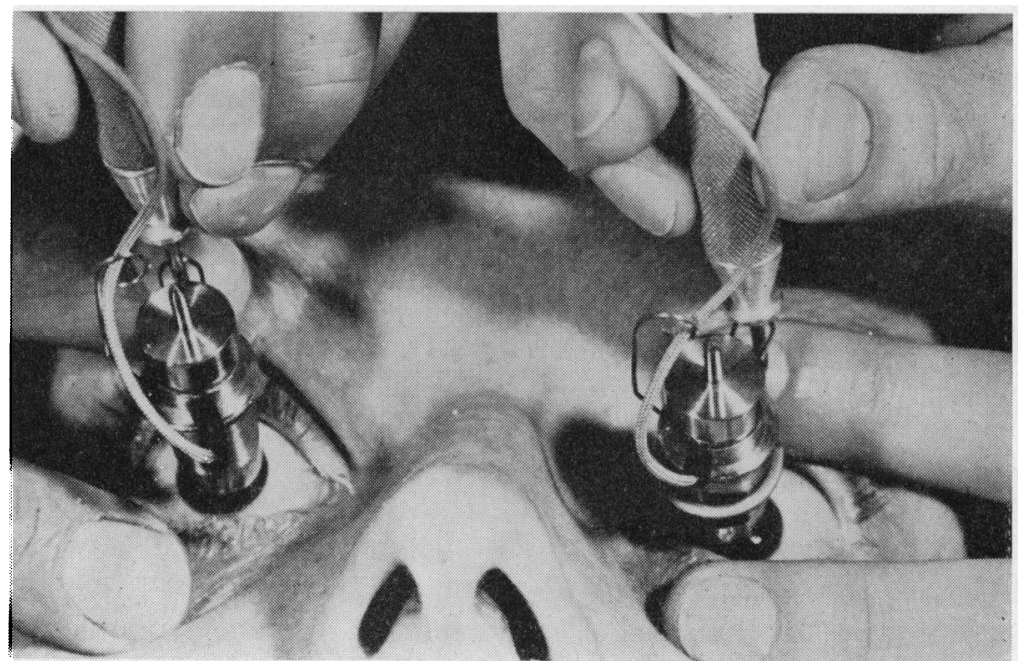

Fig. 1.-Binocular tonography.

To minimize the margin of error in the chemical test, only syringes, cannulae, and tubes which had been cleaned several times with doubly-distilled water were used for testing. Calcium heparinate served as an anticoagulant, since regular heparin has too high a sodium and potassium content.

The chloride test was done by the method of Schales and Schales: the chloride content of the serum is determined by titration with a mercury nitrate solution and

* Diamox(R acetazolamide was supplied by Lederle Laboratories, a division of American Cyanamid Company.

$\dagger$ Potassium chloride solution Elo-Mel 4 of Salvia-Werk, Homburg/Saar, was used for the infusion. 
a diphenylcarbazone indicator is added to the serum. The concentrations of potassium and sodium were determined by the Beckmann flame photometer. The total carbonic acid content of the blood was determined by van Slyke's method of blood gas analysis.

Among the 23 patients (43 eyes) who were studied, thirteen had never received Diamox ${ }^{\circledR}$ and ten had been treated with the drug for up to 3 years without supplementary electrolytes. Surgical intervention had been ineffective in some, and in others the long-term administration of miotics had not adequately controlled the intra-ocular pressure (Table I).

\section{Results}

Table II and Fig. 2 (opposite) and Table III and Fig. 3 (overleaf) summarize the aqueous dynamics and electrolyte determinations of all patients studied.

In considering the average results, it should be noted that they include the findings in patients who had already been treated with acetazolamide for prolonged periods. It should be understood that continuation of the previous therapy in this group of patients would not cause significant alterations in the equilibrium between the aqueous dynamics and the electrolyte balance already established.

Yet the average results reveal a significant fall in the intra-ocular pressure as well as a reduction in the rate of aqueous flow and a decrease in the serum potassium level immediately after the start of acetazolamide therapy. Approximately 2 weeks later, however, a gradual rise in the intra-ocular pressure and the rate of aqueous flow to levels which were still below the initial pretreatment values was noted. Potassium continued to fall, the lowest level being reached approximately 6 weeks later. After supplementation with daily doses of $1 \mathrm{~g}$. potassium chloride, a transient slight fall in tension was noted. During this phase equilibrium was eventually established, the intra-ocular pressure being lower than that noted in untreated eyes but always higher than that obtained immediately after the start of acetazolamide therapy. However, when daily doses of $2 \mathrm{~g}$. potassium chloride were given, the intra-ocular pressure and rate of aqueous flow were as low as those immediately following the start of therapy.

We agreed with other investigators in finding that acetazolamide did not markedly improve the impaired rate and ease of outflow. It was confirmed again, therefore, that the tension-lowering action of carbonic anhydrase inhibitors is based entirely on a reduced secretion of aqueous.

During the 5-month observation period, the following electrolyte changes became evident:

(1) The serum potassium level declined after the start of therapy.

(2) When daily doses of $1 \mathrm{~g}$. of potassium chloride were added to the acetazolamide, the potassium level rose somewhat but did not reach the pre-treatment concentration. 
Fig. 2.-Average values of aqueous dynamics and electrolyte determination results in all patients (eyes) studied (P, C, and $\mathbf{F}$ as in Table II).

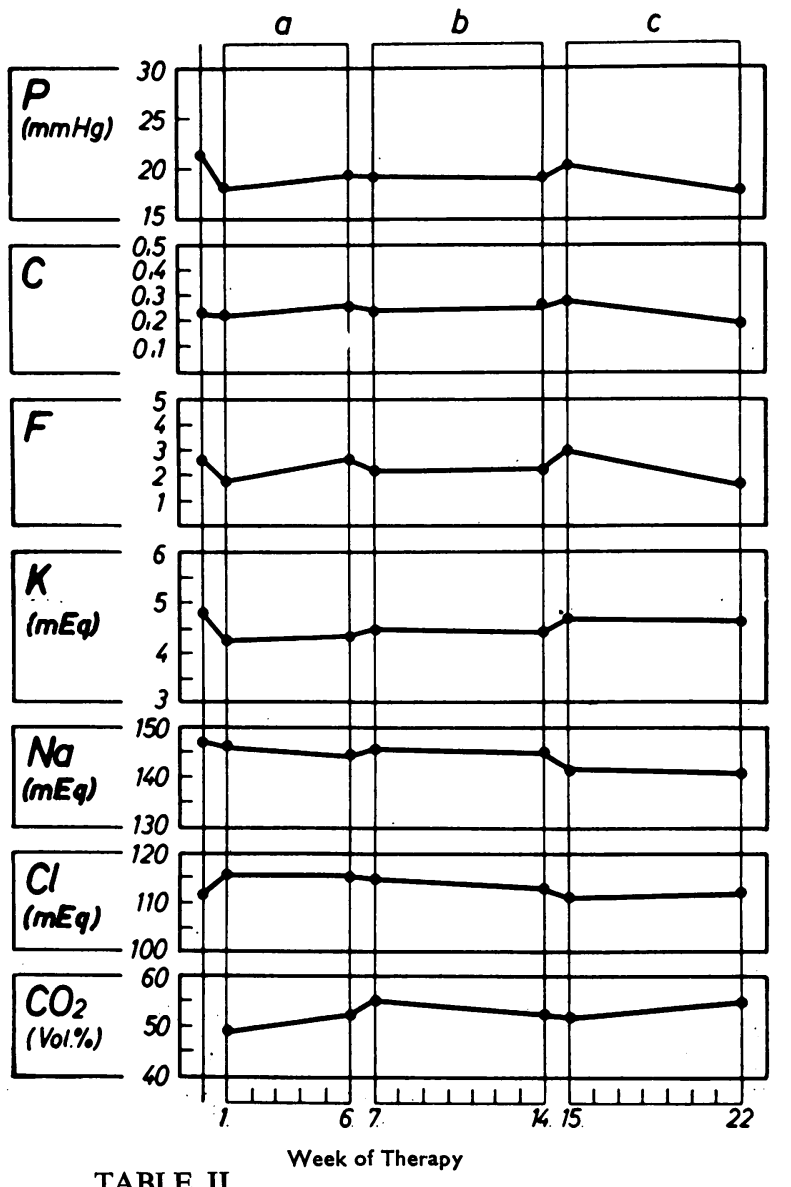

TABLE II

AVERAGE AQUEOUS DYNAMICS AND ELECTROLYTE DATA FOR ALL EYES STUDIED

\begin{tabular}{|c|c|c|c|c|c|}
\hline \multirow{2}{*}{$\begin{array}{c}\text { Serum } \\
\text { Potassium } \\
(\mathrm{mEq})\end{array}$} & \multicolumn{3}{|c|}{ Aqueous Dynamics } & \multirow{2}{*}{$\begin{array}{c}\text { 24-hr } \\
\text { Urine } \\
\text { Volume } \\
\text { (ml.) }\end{array}$} & \multirow{2}{*}{$\begin{array}{l}\text { Duration } \\
\text { of Therapy } \\
\text { (wks) }\end{array}$} \\
\hline & $\begin{array}{c}\text { Intra-ocular } \\
\text { Pressure } \\
\text { P }_{0} \\
(\mathrm{~mm} . \mathrm{Hg})\end{array}$ & $\begin{array}{c}\text { Rate and Ease } \\
\text { of Outflow } \\
\text { C } \\
\text { (cu. } \mathrm{mm} . / \mathrm{min} . / \mathrm{mm} . \mathrm{Hg} \text { ) }\end{array}$ & $\begin{array}{l}\text { Aqueous } \\
\text { Flow } \\
\text { F } \\
\text { (c. } \mathrm{mm} . / \mathrm{min} . \text { ) }\end{array}$ & & \\
\hline $\begin{array}{l}4 \cdot 83 \\
4 \cdot 41\end{array}$ & $\begin{array}{l}21 \cdot 3 \\
19 \cdot 1\end{array}$ & $\begin{array}{l}0.22 \\
0.25\end{array}$ & $\begin{array}{l}2 \cdot 56 \\
2 \cdot 35\end{array}$ & $\begin{array}{r}941 \\
1,138\end{array}$ & $\overline{1 \eta}$ \\
\hline $\begin{array}{l}4 \cdot 35 \\
4 \cdot 52\end{array}$ & $\begin{array}{l}19.4 \\
18.7\end{array}$ & $\begin{array}{l}0.22 \\
0 \cdot 26\end{array}$ & $\begin{array}{l}2 \cdot 22 \\
2 \cdot 34\end{array}$ & $\begin{array}{r}942 \\
1,056\end{array}$ & \\
\hline $\begin{array}{l}4 \cdot 36 \\
4 \cdot 74\end{array}$ & $\begin{array}{l}20 \cdot 1 \\
20 \cdot 0\end{array}$ & $\begin{array}{l}0.28 \\
0.35\end{array}$ & $\begin{array}{l}2 \cdot 94 \\
3 \cdot 10\end{array}$ & $\begin{array}{l}982 \\
980\end{array}$ & $\begin{array}{l}14 \\
15\end{array}$ \\
\hline $4 \cdot 56$ & $18 \cdot 1$ & $0 \cdot 27$ & $2 \cdot 14$ & 1,075 & 22 \\
\hline
\end{tabular}

a Acetazolamide in divided doses of $125 \mathrm{mg}$. two or three times daily.

$b$ As above plus daily supplementary $1 \mathrm{~g}$. potassium chloride.

$c$ As above plus daily supplementary $2 \mathrm{~g}$. potassium chloride. 


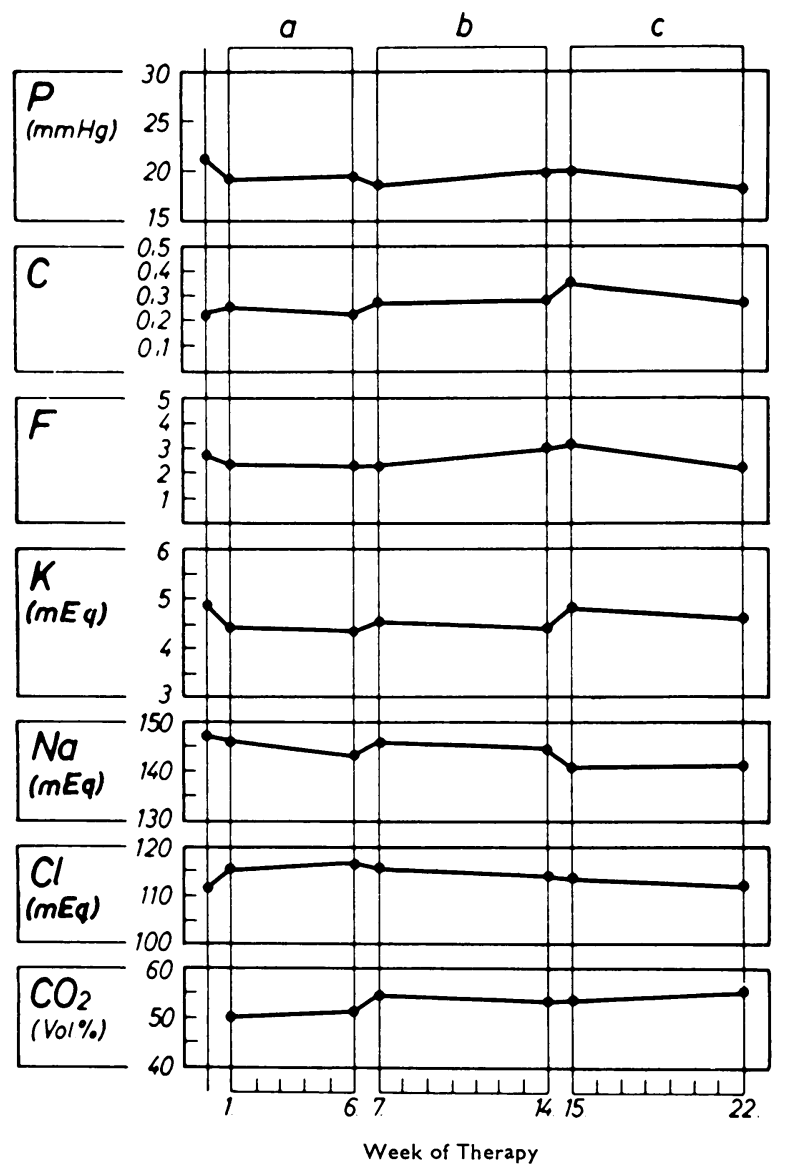

FIG. 3.-Average values of aqueous dynamics and electrolyte determination results in all patients (eyes) previously treated with acetazolamide $(P, C$, and $F$ as in Table III).

TABLE III

AVERAGE AQUEOUS DYNAMICS AND ELECTROLYTE DATA FOR EYES PREVIOUSLY TREATED WITH ACETAZOLAMIDE

\begin{tabular}{|c|c|c|c|c|c|}
\hline \multirow[b]{2}{*}{$\begin{array}{l}\text { Serum } \\
\text { Potassium } \\
(\mathrm{mEq})\end{array}$} & \multicolumn{3}{|c|}{ Aqueous Dynamics } & \multirow{2}{*}{$\begin{array}{l}\text { 24-hr } \\
\text { Urine } \\
\text { Volume } \\
\text { (ml.) }\end{array}$} & \multirow{2}{*}{$\begin{array}{l}\text { Duration } \\
\text { of Therapy } \\
\text { (wks) }\end{array}$} \\
\hline & $\begin{array}{c}\text { Intra-ocular } \\
\text { Pressure } \\
\mathrm{P}_{0} \\
(\mathrm{~mm} . \mathrm{Hg})\end{array}$ & $\begin{array}{c}\text { Rate and Ease } \\
\text { of Outflow } \\
\text { C } \\
\text { (cu. } \mathrm{mm} . / \mathrm{min} . / \mathrm{mm} . \mathrm{Hg} \text { ) }\end{array}$ & $\begin{array}{c}\text { Aqueous } \\
\text { Flow } \\
\text { F } \\
\text { (cu. } \mathrm{mm} . / \mathrm{min} . \text { ) }\end{array}$ & & \\
\hline $\begin{array}{l}4 \cdot 83 \\
4 \cdot 19\end{array}$ & $\begin{array}{l}21 \cdot 3 \\
18 \cdot 2\end{array}$ & $\begin{array}{l}0.22 \\
0.21\end{array}$ & $\begin{array}{l}2 \cdot 56 \\
1 \cdot 77\end{array}$ & $\begin{array}{r}941 \\
1,138\end{array}$ & $\overline{17}$ \\
\hline $\begin{array}{l}4 \cdot 25 \\
4 \cdot 41\end{array}$ & $\begin{array}{l}19 \cdot 3 \\
19 \cdot 3\end{array}$ & $\begin{array}{l}0 \cdot 26 \\
0 \cdot 24\end{array}$ & $\begin{array}{l}2 \cdot 72 \\
2 \cdot 12\end{array}$ & $\begin{array}{r}922 \\
1,007\end{array}$ & $\begin{array}{l}6 \\
7\end{array}$ \\
\hline $\begin{array}{l}4 \cdot 41 \\
4 \cdot 65\end{array}$ & $\begin{array}{l}19 \cdot 1 \\
20 \cdot 4\end{array}$ & $\begin{array}{l}0.25 \\
0.27\end{array}$ & $\begin{array}{l}2 \cdot 36 \\
3 \cdot 00\end{array}$ & $\begin{array}{l}904 \\
978\end{array}$ & $\begin{array}{l}14 \\
15\end{array}$ \\
\hline $4 \cdot 60$ & $17 \cdot 5$ & $0 \cdot 19$ & $1 \cdot 64$ & 1,025 & 22 \\
\hline
\end{tabular}

$a, b, c$ as in Table II. 
(3) When the daily potassium supplement was increased to $2 \mathrm{~g}$, the serum potassium level returned to the level noted before the start of treatment. Thus a correlation appears to exist between the height of the intra-ocular pressure and the rate of aqueous flow and the concentration of potassium ions in the blood. A fall in serum potassium is accompanied by a decrease in activity of the carbonic anhydrase inhibitor.

Table IV and Fig. 4 (overleaf) show the average values in patients who received acetazolamide for the first time. They should be compared with those noted in patients who had been receiving it for up to 3 years (Table III, Fig. 3). As expected, differences between the two groups were evident only during the initial phase of the study. While a definite decrease in the serum potassium level, the intra-ocular pressure, and the rate of aqueous flow is evident in the former group, this series of events is much less evident in the latter group. This is because the decreases in the latter group merely reflect the changes in dosage which had to be made in some patients to adapt them to the standardized conditions of this study.

Subsequently, in the course of the investigation, when supplementary potassium was added no significant differences were seen. Only after the daily administration of $2 \mathrm{~g}$. of potassium chloride was started was there a significant decrease in intra-ocular pressure and rate of aqueous flow, and a rise to normal of the serum potassium level.

\section{Case Histories}

Case 1, a 68-year-old patient, had bilateral chronic simple glaucoma not adequately controlled by previous therapy with miotics (Fig. 5 and Table V, overleaf).

The intra-ocular pressure recorded by the applanation tonometer was $30 \mathrm{~mm} . \mathrm{Hg}$ in the right eye and $21.5 \mathrm{~mm}$. Hg in the left. No significant functional and morphological glaucomatous changes were seen. However, tonography revealed bilateral moderate impairment of the rate and ease of outflow, more marked in the right than in the left eye, though with an approximately normal rate of aqueous formation. Divided doses of $125 \mathrm{mg}$. acetazolamide were given three times a day and the intra-ocular pressure in both eyes fell to $20 \mathrm{~mm}$. Hg; this was associated with a significant decrease in the rate of aqueous formation and the serum potassium level. 4 weeks later the tension rose slightly in the right eye. This appeared to be due to a concomitantly observed increase in the rate of aqueous formation, as no significant changes in the rate and ease of outflow were noted.

Supplementary therapy with potassium chloride was followed by a fall in intra-ocular tension and the rate of aqueous formation, and a simultaneous rise in the serum potassium level. Very soon, however, the intra-ocular pressure again rose slightly. Only when the daily dose of potassium chloride was increased to $2 \mathrm{~g}$. did the bilateral intra-ocular pressure again fall below $20 \mathrm{~mm}$. $\mathrm{Hg}$, with a simultaneous marked decline in the rate of aqueous formation. No side-effects of any significance were noted. The functional and morphological findings previously noted remained unchanged.

Case 2, a 74-year-old patient, had bilateral chronic simple glaucoma, inadequately controlled by miotics, and surgery was not indicated (Fig. 6 and Table VI, overleaf).

Early signs of Bjerrum scotoma had been detected in the right visual field. In the left visual field the internal and external isopters were intact with no enlargement of the 


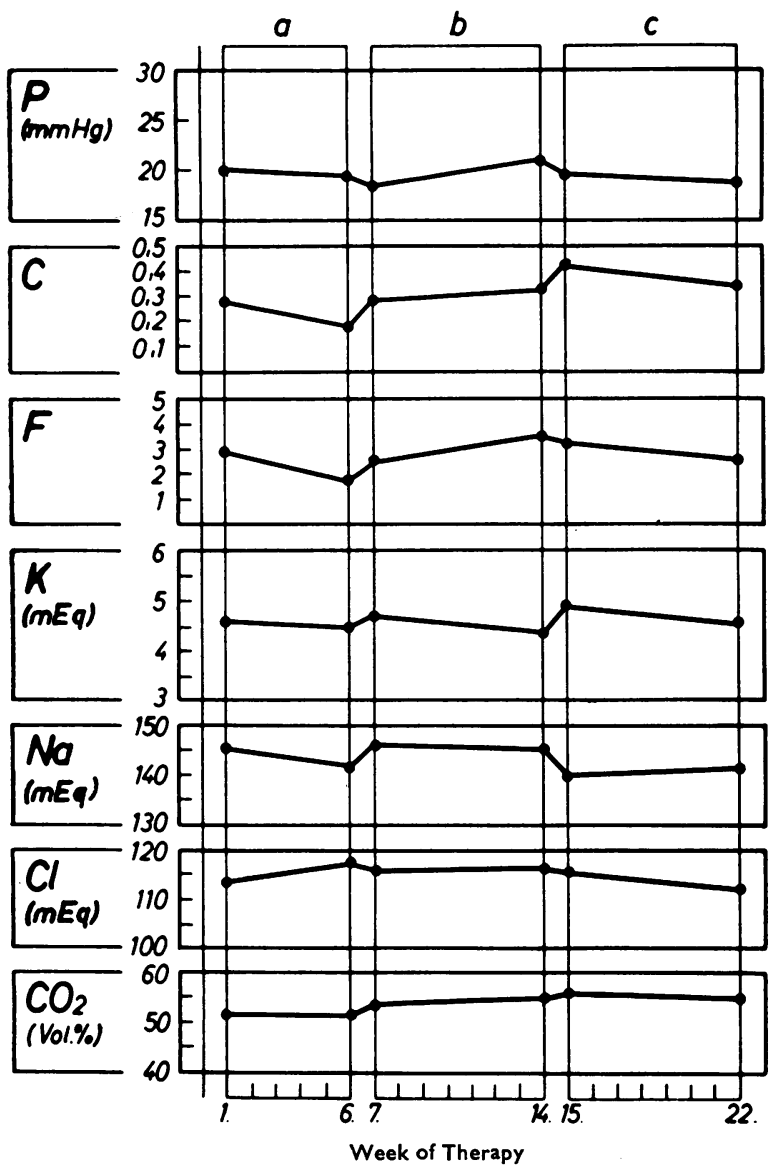

FIG. 4.-Average values of aqueous dynamics and electrolyte determination results in all patients (eyes) treated with acetazolamide for the first time.

TABLE IV

AVERAGE AQUEOUS DYNAMICS AND ELECTROLYTE DATA FOR EYÉS TREATED WITH ACETAZOLAMIDE FOR THE FIRST TIME

\begin{tabular}{|c|c|c|c|c|c|}
\hline \multirow[b]{2}{*}{$\begin{array}{l}\text { Serum } \\
\text { Potassium } \\
(\mathrm{mEq})\end{array}$} & \multicolumn{3}{|c|}{ Aqueous Dynamics } & \multirow{2}{*}{$\begin{array}{l}\text { 24-hr } \\
\text { Urine } \\
\text { Volume } \\
\text { (ml.) }\end{array}$} & \multirow{2}{*}{$\begin{array}{l}\text { Duration } \\
\text { of Therapy } \\
\text { (wks) }\end{array}$} \\
\hline & $\begin{array}{c}\text { Intra-ocular } \\
\text { Pressure } \\
\mathbf{P}_{0} \\
\text { (mm. Hg) }\end{array}$ & $\begin{array}{c}\text { Rate and Ease } \\
\text { of Outflow } \\
\text { (cu. } \mathrm{mm} . / \mathrm{min} . / \mathrm{mm} . \mathrm{Hg} \text { ) }\end{array}$ & $\begin{array}{c}\text { Aqueous } \\
\text { Flow } \\
\text { F } \\
\text { (cu. } \mathrm{mm} . / \mathrm{min} . \text { ) }\end{array}$ & & \\
\hline $4 \cdot 62$ & $19 \cdot 9$ & 0.28 & $2 \cdot 93$ & 1,138 & \multirow{4}{*}{$\left.\begin{array}{r}1 \\
6 \\
7 \\
14 \\
15 \\
22\end{array}\right\}$} \\
\hline $\begin{array}{l}4 \cdot 44 \\
4 \cdot 62\end{array}$ & $\begin{array}{l}19 \cdot 4 \\
18 \cdot 1\end{array}$ & $\begin{array}{l}0.18 \\
0.28\end{array}$ & $\begin{array}{l}1 \cdot 72 \\
2 \cdot 56\end{array}$ & $\begin{array}{r}962 \\
1,104\end{array}$ & \\
\hline $\begin{array}{l}4 \cdot 31 \\
4 \cdot 83\end{array}$ & $\begin{array}{l}21 \cdot 0 \\
19 \cdot 5\end{array}$ & $\begin{array}{l}0.31 \\
0.43\end{array}$ & $\begin{array}{l}3 \cdot 52 \\
3 \cdot 19\end{array}$ & $\begin{array}{r}1,059 \\
981\end{array}$ & \\
\hline $4 \cdot 51$ & $18 \cdot 4$ & $0 \cdot 34$ & $2 \cdot 63$ & 1,124 & \\
\hline
\end{tabular}

$a, b, c$ as in Table II. 
FIG. 5.-Intra-ocular pressure, rate of aqueous flow, and serum electrolyte levels during longterm administration of acetazolamide with supplementary potassium in a 68-year-old patient with bilateral chronic simple glaucoma.

Left eye

Right eye-

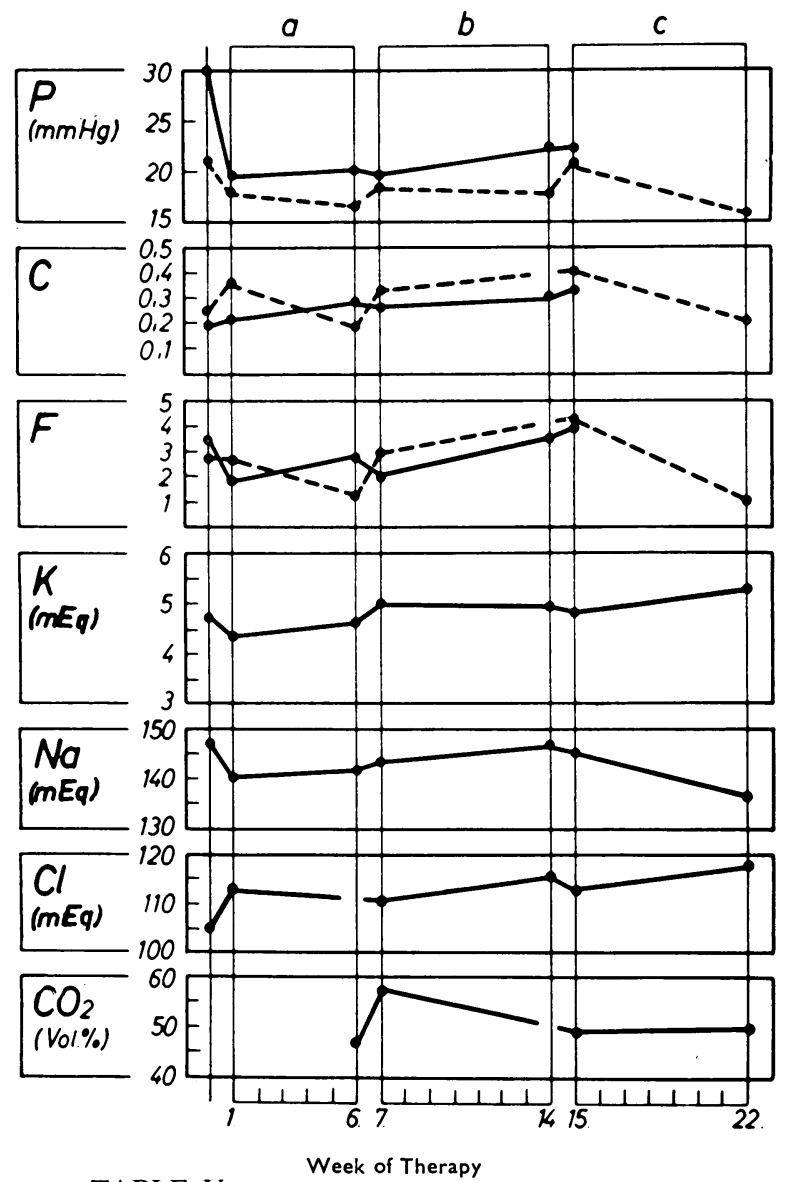

TABLE V

68-YEAR-OLD PATIENT WITH BILATERAL CHRONIC SIMPLE GLAUCOMA

\begin{tabular}{|c|c|c|c|c|c|}
\hline \multirow[b]{2}{*}{$\begin{array}{l}\text { Serum } \\
\text { Potassium } \\
\text { (mEq) }\end{array}$} & \multicolumn{3}{|c|}{ Aqueous Dynamics } & \multirow[b]{2}{*}{$\begin{array}{l}\text { 24-hr } \\
\text { Urine } \\
\text { Volume } \\
\text { (ml.) }\end{array}$} & \multirow[b]{2}{*}{$\begin{array}{l}\text { Duration } \\
\text { of Therapy } \\
\text { (wks) }\end{array}$} \\
\hline & $\begin{array}{c}\text { Intra-ocular } \\
\text { Pressure } \\
\mathrm{P}_{0} \\
(\mathrm{~mm} . \mathrm{Hg}) \\
\end{array}$ & $\begin{array}{c}\text { Rate and Ease } \\
\text { of Outflow } \\
\text { C } \\
\text { (cu. } \mathrm{mm} . / \mathrm{min} . / \mathrm{mm} . \mathrm{Hg} \text { ) }\end{array}$ & $\begin{array}{c}\text { Aqueous } \\
\text { Flow } \\
F \\
\text { (cu. } \mathrm{mm} . / \mathrm{min} . \text { ) }\end{array}$ & & \\
\hline $\begin{array}{l}4 \cdot 69 \\
4 \cdot 33\end{array}$ & $\begin{array}{l}30 \cdot 0 \\
21 \cdot 3 \\
19 \cdot 3 \\
17 \cdot 4 \\
\end{array}$ & $\begin{array}{l}0.18 \\
0.25 \\
0.20 \\
0.36\end{array}$ & $\begin{array}{l}3 \cdot 60 \\
2 \cdot 82 \\
1 \cdot 86 \\
2 \cdot 66\end{array}$ & - & - \\
\hline $\begin{array}{l}4 \cdot 53 \\
4 \cdot 99\end{array}$ & $\begin{array}{l}20 \cdot 1 \\
16 \cdot 7 \\
17 \cdot 9 \\
18 \cdot 5\end{array}$ & $\begin{array}{l}0 \cdot 28 \\
0 \cdot 18 \\
0 \cdot 27 \\
0 \cdot 34 \\
\end{array}$ & $\begin{array}{l}2 \cdot 83 \\
1 \cdot 21 \\
2 \cdot 13 \\
2 \cdot 89\end{array}$ & $\begin{array}{r}1,090 \\
670\end{array}$ & $7)$ \\
\hline $4 \cdot 89$ & $\begin{array}{l}22 \cdot 3 \\
17 \cdot 9\end{array}$ & $\begin{array}{c}0.28 \\
-\end{array}$ & $3 \cdot 44$ & 500 & $14 \int^{0}$ \\
\hline $4 \cdot 81$ & $\begin{array}{l}22 \cdot 3 \\
20 \cdot 7 \\
\end{array}$ & $\begin{array}{l}0 \cdot 32 \\
0.40 \\
\end{array}$ & $\begin{array}{l}3 \cdot 94 \\
4 \cdot 28 \\
\end{array}$ & 700 & $\left.{ }^{15}\right\}_{c}$ \\
\hline $5 \cdot 29$ & $\overline{15 \cdot 5}$ & $\overline{0 \cdot 21}$ & $\overline{1 \cdot 15}$ & 630 & 22 \\
\hline
\end{tabular}

$a, b, c$ as in Table II.

30 


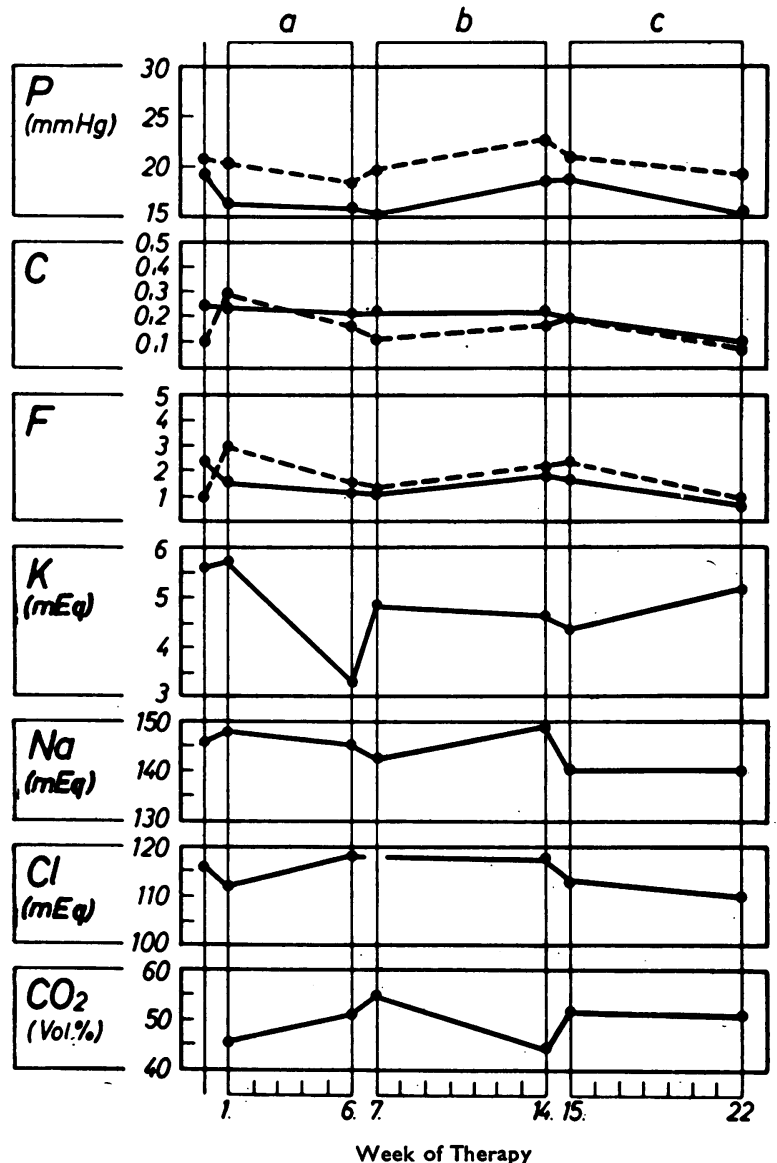

TABLE VI
Fig. 6.-Intra-ocular pressure, rate of aqueous flow, and serum electrolyte levels during longterm administration of acetazolamide with supplementary potassium in a 74-year-old patient with bilateral chronic simple glaucoma.

Left eye.$\ldots \ldots \ldots \ldots$

Right eye

\section{4-YEAR-OLD PATIENT WITH BILATERAL CHRONIC SIMPLE GLAUCOMA}

\begin{tabular}{|c|c|c|c|c|c|}
\hline \multirow[b]{2}{*}{$\begin{array}{l}\text { Serum } \\
\text { Potassium } \\
(\mathrm{mEq})\end{array}$} & \multicolumn{3}{|c|}{ Aqueous Dynamics } & \multirow[b]{2}{*}{$\begin{array}{l}\text { 24-hr } \\
\text { Urine } \\
\text { Volume } \\
\text { (ml.) }\end{array}$} & \multirow[b]{2}{*}{$\begin{array}{l}\text { Duration } \\
\text { of Therapy } \\
\text { (wks) }\end{array}$} \\
\hline & $\begin{array}{c}\text { Intra-ocular } \\
\text { Pressure } \\
\mathbf{P}_{0} \\
\text { (mm. } \mathrm{Hg})\end{array}$ & $\begin{array}{l}\text { Rate and Ease of } \\
\text { Outflow } \\
\text { (cu. } \mathrm{mm} . / \mathrm{min} . / \mathrm{mm} . \mathrm{Hg} \text { ) }\end{array}$ & $\begin{array}{c}\text { Aqueous } \\
\text { Flow } \\
\text { F } \\
\text { (cu. } \mathrm{mm} . / \mathrm{min} \text {.) }\end{array}$ & & \\
\hline $\begin{array}{l}5 \cdot 58 \\
5 \cdot 73\end{array}$ & $\begin{array}{l}19 \cdot 7 \\
20 \cdot 8 \\
16 \cdot 2 \\
20 \cdot 2\end{array}$ & $\begin{array}{l}0.24 \\
0.09 \\
0.23 \\
0.29\end{array}$ & $\begin{array}{l}2.33 \\
0.97 \\
1.42 \\
2.96\end{array}$ & $\begin{array}{l}1,830 \\
1,630\end{array}$ & - \\
\hline $\begin{array}{l}3 \cdot 25 \\
4 \cdot 81\end{array}$ & $\begin{array}{l}15 \cdot 7 \\
18 \cdot 4 \\
15 \cdot 2 \\
19 \cdot 6\end{array}$ & $\begin{array}{l}0 \cdot 20 \\
0 \cdot 17 \\
0 \cdot 20 \\
0 \cdot 12\end{array}$ & $\begin{array}{l}1 \cdot 14 \\
1 \cdot 44 \\
1 \cdot 04 \\
1 \cdot 15\end{array}$ & $\begin{array}{l}1,240 \\
1,100\end{array}$ & $\begin{array}{l}6) \\
7\end{array}$ \\
\hline $\begin{array}{l}4 \cdot 64 \\
4 \cdot 30\end{array}$ & $\begin{array}{l}18 \cdot 5 \\
22 \cdot 8 \\
18 \cdot 5 \\
21 \cdot 2\end{array}$ & $\begin{array}{l}0 \cdot 21 \\
0 \cdot 17 \\
0 \cdot 19 \\
0 \cdot 20\end{array}$ & $\begin{array}{l}1 \cdot 78 \\
2 \cdot 18 \\
1 \cdot 61 \\
2 \cdot 24\end{array}$ & $\begin{array}{l}1,475 \\
1,635\end{array}$ & $\begin{array}{l}14 \\
15\end{array}$ \\
\hline $5 \cdot 12$ & $\begin{array}{l}15 \cdot 2 \\
19 \cdot 0\end{array}$ & $\begin{array}{l}0 \cdot 10 \\
0.08\end{array}$ & $\begin{array}{l}0.52 \\
0.72\end{array}$ & 1,425 & 22 \\
\hline
\end{tabular}

$a, b, c$ as in Table II. 
blind spot. Administration of acetazolamide in divided doses of $125 \mathrm{mg}$. three times a day reduced the intra-ocular pressure for some time, but gradually became ineffective. Only when daily doses of $2 \mathrm{~g}$. potassium chloride were added was this tendency controlled. This patient had no untoward side-reactions. The functional and morphological findings noted before starting therapy remained unchanged.

During the initial phase of therapy a few patients experienced slight sidereactions, such as paraesthesia, lassitude, or anorexia, all of which subsided when supplementary therapy with potassium was started. None of our patients had the transitory myopia which has been mentioned by other authors as a side-effect. Two patients complained of a gastric upset when supplementary potassium was first given, but it was found that they had erroneously received capsules of potassium chloride which disintegrate in the stomach instead of those prescribed which break up in the small intestine. The disturbance subsided immediately the form of administration was changed.

Intravenous infusion of potassium chloride was given to some patients, and was well tolerated by all with no side-reactions.

\section{Conclusion}

Continued long-term administration of carbonic inhibitors in the treatment of glaucoma is perfectly feasible if attention is given to the shift in the electrolyte balance which takes place during such therapy. Control of intra-ocular pressure can be maintained in this way for a long time, and any loss in efficacy and untoward side-reactions can be eliminated by correcting the potassium deficiency. However, it is important that supplementary potassium should be given in large enough doses, a daily amount of not less than $2 \mathrm{~g}$. potassium chloride or $2.7 \mathrm{~g}$. potassium bicarbonate. Whenever possible the amount given should be guided by the serum electrolyte determinations. These compounds are not only useful for the short-term therapy of refractory glaucoma, but enhance the feasibility of conservative long-term therapy when surgery is not indicated or has been ineffective.

\section{Summary}

With continued long-term administration of carbonic anhydrase inhibitors, some patients experience untoward side-reactions and the drugs gradually become less effective. Electrolyte studies conducted while the patients were being treated with these drugs indicate that the potassium deficiency which occurs during such therapy is the basic cause. 23 patients with various forms of glaucoma received acetazolamide and supplementary potassium over a period of 5 months. When daily doses of $2 \mathrm{~g}$. potassium chloride are added the side-effects subside, the intra-ocular pressure falls to the levels recorded immediately after the initiation of therapy, and the tonographic tracings show a significant decline in the rate of aqueous formation. Potassium can be given intravenously as potassium chloride or potassium 
bicarbonate, but the potassium ion content of the latter should equal that of the former. It is, therefore, recommended that supplementary potassium, in a suitable form and in adequate amounts, should be given during the longterm administration of carbonic anhydrase inhibitors. The administration of potassium should be guided by the results of spaced serum electrolyte determinations.

\section{REFERENCES}

BECKER, B. (1954). Amer. J. Ophthal., 37, 13.

Breinin G. M., and GõRTZ, H. (1954). A.M.A. Arch. Ophthal., 52, 333.

DrAeger, J. (1959a). In Verh. österr. ophthal. Ges., p. 23. - (1959b). Docum. ophthal., 13, 431.

Grant, W. M. (1950). A.M.A. Arch. Ophthal., 44, 204. (1951). Ibid., 46, 113.

HOFFMEISTER, W., and KRÜCK, F. (1956). Klin. Wschr., 34, 394.

(1957). Therapiewoche, Aug./Sept., 14/15.

RAISP, I. (1959). Wein. med. Wschr., 109, 772. 